KYIV-MOHYLA

HUMANITIES JOURNAL

KYIV-MOHYLA SCHOLARLY PEER-REVIEWED JOURNALS

Orthodox Christian Biblical Studies in Pursuit of Identity: The Role and Impact of Personal Research Practices

Author(s): Sergiy Golovashchenko

Source: Kyiv-Mohyla Humanities Journal 3 (2016): 105-121

Published by: National University of Kyiv-Mohyla Academy

http://kmhj.ukma.edu.ua/ 


\title{
Orthodox Christian Biblical Studies in Pursuit of Identity: The Role and Impact of Personal Research Practices
}

\author{
Sergiy Golovashchenko \\ National University of Kyiv-Mohyla Academy, \\ Department of Philosophy and Religious Studies
}

\begin{abstract}
The article explores the pursuit of identity in Ukrainian Orthodox biblical studies not only in liturgical, exegetical, moral, educational and apologetic dimensions, but also from the perspective of academic criticism. It reviews the key points of this process, as discovered in the legacy of prominent representatives of the Kyivan biblical study tradition. Governmental influence on the Church's educational policies, balancing between loyalty to the Orthodox tradition and Western biblical criticism, is among the factors that have shaped biblical studies, this issue being explored in the article. Historical milestones of biblical studies are presented, as is the research of prominent Kyivan scholars. Considering all these aspects and other crucial issues, the conclusion shows what makes the Kyivan tradition of biblical studies unique and of lasting importance.
\end{abstract}

Key Words: Bible, biblical studies, Orthodox Church, theology, religious studies, Kyiv Theological Academy.

\section{(2)}

\section{Introduction}

The research of the tradition of biblical studies at the Kyiv Theological Academy (KTA), which the author has been exploring for the past several years, includes a review of the legacy of both individual researchers and the entire professional community that generates knowledge about the Bible, lectures on it in the academic environment, and disseminates it for popular educational purposes. ${ }^{1}$ This research has exposed how important it is to explore this phenomenon both in terms of its institutional evolution and the personal research practices

1

See S. I. Golovashchenko, Doslidzhennia ta vykladannia Biblii v Kyivskii dukhovnii akademii XIX — pochatku XX st. [Research and Instruction of the Bible at the Kyiv Theological Academy in the 1gth and Early 2oth Centuries] (Kyiv: Vydavnychyi viddil Ukrainskoi Pravoslavnoi Tserkvy, 2012); S. I. Golovashchenko, "Bibliieznavstvo v Kyivskii dukhovnii akademii (XIX — poch. XX st.): stanovlennia i rozvytok [Biblical Studies at the Kyiv Theological Academy (the 19th and Early 2oth Centuries): Evolvement and Development]" (Thesis for Doctor of Philosophy Degree in Specialization 09.0o.11 — Religious Studies, National Pedagogical Drahomanov University, Kyiv, 2015). 
of prominent representatives of that tradition. ${ }^{2}$ Especially because the use of elements of prosopographic and biographic analysis has elucidated the methods - specific for the social environment, historical period, and religious denomination - in which knowledge about the Bible is generated and transmitted, and exposed these methods in the experiences of the given professional group and its individual representatives. After all, the tradition of biblical studies at the Kyiv Theological Academy in the 19th and early 2oth centuries took its distinctive shape due to the activity of a whole academic community of researchers and professors who were united in the same communication environment, had inherited the same categorical vocabulary, hermeneutical principles of biblical studies, its scholastic nature, disciplinary instruction in academic departments, a specific professor-student connection in the retransmission of knowledge, and a critical reception of achievements made by other biblical study traditions.

In turn, the methodological focus on the research of biblical studies as a history of the exploration of the sacred text dominant in Ukrainian religious culture prompted the taking into account of the dual nature of the Bible - as both as the Word of God and the word of men in the perception of the scholars who were Orthodox Christian believers and viewed the Bible primarily as the Holy Scriptures of their own religious denomination. It requires making an interpretive effort to grasp their ideological and moral motives, theoretical views, and specific research techniques. As is known, this is how the hermeneutic approach is implemented, where a researcher makes some effort to interpret the intentions of a believer, focusing his or her mind on finding a way to communicate with God; and this is how the researcher engages in a dialogue with the history of a religious tradition. ${ }^{3}$

The use of the hermeneutic method requires taking into account the historical interconnection and synthesis of various hermeneutic paradigms and approaches to understanding the phenomenon of the Bible, which took place for several centuries - especially in the 19th and early 2oth centuries in Kyiv academic theological culture, and was reflected in the academic theological works of leading Kyivan biblical scholars. The exploration of the Bible, fused with their personal life and research and translation experience, arises here in its scholastic dimension as a dialogue of cultures and traditions, centered on the individual who perceives himself or herself as both the key bearer of the tradition and the actual participant of the dialogue. ${ }^{4}$

Therefore, accumulated sources and facts have led to the interpretation of the personal scholarly activity of Kyivan biblical researchers from a somewhat new, but in fact quite anticipated, angle. It is about identifying the basis for the development of the identity of Ukrainian Orthodox biblical studies and their religious and academic specificity in the past few centuries. Earlier in history, this issue has objectively emerged during the transformation of traditional medieval Orthodox Christian Church practices. This transformation took place

2 This issue is addressed in a separate article soon to be published in Naukovi zapysky NaUKMA.

3 A. Kolodnyi and A. Lobovyk, eds., Relihiieznavstvo: predmet, struktura, metodolohiia [Religious Studies: Subject Matter, Structure, Methodology] (Kyiv: Viddil relihiieznavstva Instytutu filosofii NAN Ukrainy, 1996), 69, 71. 
throughout the entire modern period as Orthodox Christianity was influenced by Western theological practices - Catholic and Protestant.

It became especially distinctive during the nineteenth century when the Russian Empire reformed Orthodox Christian theological education and strengthened the system of mass propaganda of Orthodoxvalues. This process was wave-like rather than continuous, with attempts at reforms (not always successful) succeeded by reactionism. The main vector of theological development was determined and adjusted by apologetic demands of governmentalized church institutions. It was then that Western academic and theological influences significantly increased the debates about an independent and original development of Orthodox Christian biblical studies and theology overall — all the way to the exacerbated anti-Western phobias of various sorts.

The Orthodox Christian tradition of biblical studies entered the twentieth century with the same issue. At the time, Orthodox Christian researchers of the Bible, mainly in European and American emigration, had to define their theoretical, methodological, and instructional positions. Adherence to Orthodox dogmatic guidelines and own liturgical traditions had to be accorded with the challenges of theological traditions of different faiths and, what is extremely important, with the demands of academic rationality. Today, at the beginning of the 21st century, the social and cultural environment has become more favorable for the development of theological knowledge, and intellectual contact with traditions of other religious denominations is technically not a problem. But exactly because of this, the understanding and assertion of the specificity of the Orthodox Christian interpretation of the Bible in the national religious, cultural and educational environment remains important even today.

Therefore, we believe it is necessary and possible to address, in this article, some key, in our opinion, theoretical and historical aspects of how the denominational, cultural, and intellectual identity of the Ukrainian Orthodox Christian tradition in biblical studies emerged and developed. It is worth underscoring that these aspects are being explored with a focus on the personal research practices of prominent Kyivan biblical researchers of different times, and on the fact that the characteristics of each historical period have always been discovered through the prism of personal life and intellectual experience.

\section{Defining the Ukrainian Tradition of Biblical Studies as "Orthodox Christian" and "Kyivan": Institutional and Personalistic Indicators}

At some point, one of our most exigent objectives was to define the subject matter of our research, i.e. the Kyivan tradition of biblical studies, specifically as "Orthodox Christian" and "Kyivan." Obviously, the goal was to consider the denominational specifics of the Orthodox Christian culture in terms of how the Bible, as a sacred text, is read, studied and interpreted. This included the unique role of the liturgical reading of biblical texts and the associated dominance of socalled "homiletic" exegesis. This para-liturgical practice had significantly distanced Orthodox 
Christian exploration of the Bible from the Western biblical and theological culture which was based more on rational criticism with its distinct "bookishness." 5

Furthermore, the goal was to reveal the identity of a certain tradition of Orthodox Christian biblical studies in connection with the local cultural and educational institutions and personalized research practices. Our study subsequently focused on the special intellectual and educational practice institutionally embodied in the work of the Orthodox Christian theological (ecclesiastical) schools, namely the Kyiv-Mohyla Academy (KMA, late 17th and 18th centuries) and the Kyiv Theological Academy (19th and early 2oth centuries). The characteristic features of this practice included the following: 1) research and educational activity of students and professors in these institutions in certain specific areas of biblical studies, 2) transmission of biblical knowledge in time through the professor-student relationship, and 3) dissemination of knowledge beyond these schools through external contacts with other educational institutions and through educational activity.

The affiliation of any Bible scholars in the Kyivan Orthodox Christian tradition of biblical studies was determined by a complex interaction of a number of essential factors. From the formal institutional perspective, it included researches and narratives made at the above theological (ecclesiastic) schools by representatives of the Orthodox Christian Church, both clergy and laity. In the ideological sense, it refers to the commitment of these researchers and professors to Orthodox dogmas, rules of exegesis and apologetics (mainly those of the patristic, especially the Eastern, tradition). This loyalty determined their own research positions and types of contacts with the "non-Orthodox" research strategies and practices when such contact took place. The originality of disciplines revealed itself in the local specifics of research topics and subjects.

The personal dimension of this affiliation was objectively determined by studies at the KMA-KTA, biblical disciplines taught at this academy, theological dissertations defended, and the publication of Bible studies. The subjective dimension of personal affiliation included commitment of individual researchers to the profession, and belief in the lasting importance of Bible studies for the spiritual, religious, moral, and intellectual development of the individual and society. ${ }^{6}$

In this manner, key but fairly obvious underpinnings have been set for the identification of Kyivan Orthodox Christian biblical studies. They were associated with the Orthodox Christian tradition as a whole and allowed viewing Orthodox biblical studies in terms of "bibliology," "biblical exegesis," and "application of the Bible." 7 However, the next interesting objective was to

5 See "Pismo Prof. Gansa Erenberga prot. S. Bulgakovu o pravoslavii i protestantizme i otvet prot.

S. Bulgakova [Letter by Prof. Hans Ehrenberg to Prot. S. Bulgakov about Orthodoxy and Protestantism and reply by S. Bulgakov]," in Put, ed. N. A. Berdyaev (Paris, 1925), 90-91.

6 S. I. Golovashchenko, "Bibliieznavstvo v Kyivskii dukhovnii akademii (XIX — poch. XX st.): deiaki poniatiino-terminolohichni pytannia doslidzhennia [Biblical Studies at the Kyiv Theological Academy (the 19th and Early 2oth Centuries): Some Conceptual and Terminological Issues of Research]," Naukovi zapysky NaUKMA 154 (2014): 87.

7 See S. M. Solskii, "Kratkii ocherk istorii Sviaschennoi bibliologii i ekzegetiki [Overview of the Story of Holy Bibliology and Exegetics]," TKDA 10 (1866): 157-90; 11 (1866): 305-42; 12 (1866): 466-506; 
identify the less obvious grounds for the identification of the Orthodox Christian biblical study tradition. These are the grounds that would allow speaking not only of traditional exegesis and apologetics but also of rational criticism of the Bible, the criticism that took shape in the nineteenth century and was defined as Bible studies (bibleistics).

It was a branch of knowledge, a certain methodological and disciplinary direction in a broader array of Bible researches, which was specific due to its rational academic application of historical, linguistic, and literary criticism to the analysis and interpretation of biblical texts. By inheriting the methods and achievements of traditional textual ("low") criticism of the Bible and by being submerged in hermeneutic research and practices of modern times during the 18th and 19th centuries, the "bibleistic" trend developed in various forms of European "high" (historical, linguistic and literary) biblical criticism.

The problem for the Orthodox Christians was that they were inclined, for quite a long time (almost to the beginning of the twentieth century), to view this notion as pertinent to the research trend linked mainly to the "alien," "non-Orthodox" (mainly Protestant) traditions, and immersed deeply in the most critical rationalist methodology. So they tried to distance themselves from it. ${ }^{8}$ This problem was exacerbated by the fact that contact with Western biblical studies was inevitable in the nineteenth century and was a factor in prompting the selfidentification of Orthodox biblical studies and a fundamental impulse for its development. ${ }^{9}$ Moreover, a methodological trend had just started to take place in global biblical studies of that time, toward making a theoretical distinction between dogmatic and academic issues, a kind of dogmatic "pressure relief" for the historical academic study of the biblical text. ${ }^{10}$ However, the then church leadership perceived any attempts to critically compare Orthodox and Western methods of biblical criticism and biblical interpretation, and the application of the methods and data of various sciences, as "uncritical dependence," "compilativity," "Western inertia," and "trust in answers given by other people." 1

S. M. Solskii, "Upotreblenie i izuchenie Biblii v Rossii ot krescheniia Rusi i do XV v. [The Use and Study of the Bible in Russia from the Christianization of Rus Through the 15th Century]," Pravoslavnoe obozrenie 27.10 (1868): 145-80; 27.11 (1868): 251-70.

8 Golovashchenko, "Bibliieznavstvo v Kyivskii dukhovnii akademii," 84-85.

$9 \quad$ I. N. Korolkov, "Preosviaschennyi Filaret, Ep. Rizhskii, kak rektor KDA [His Grace Filaret, Bishop of Riga as the Rector of the KTA]," TKDA 12 (1882): 11, 19, 20, 51; I. I. Malyshevskii, "Istoricheskaia zapiska o sostoianii akademii v minuvshee piatidesiatiletie [Historical Review of the Status of the Academy in the Past Half-Century]," TKDA 11 (1869): 121-22; Fedor Titov, Prof. Prot., Imperatorskaia Kievskaia Dukhovnaia Akademiia v yeie trekhvekovoi zhizni i deiatelnosti (1615-1915 gg.): Istoricheskaia zapiska [The Imperial Kiev Theological Academy in Its Three Centuries of Life and Activity, 1615-1915: Historical Review] (Kyiv: Hopak, 2003), 400, 758, 296.

10 Alexandr Men, Prot., "K istorii russkoi pravoslavnoi bibleistiki [On the History of Russian Orthodox Biblical Studies]," Bogoslovskie trudy 28 (1987): 284-85; Alexandr Men, Prot., Bibliologicheskii slovar [Bibliological Dictionary], vol. 1, 63, 66.

11 I. N. Korolkov, “Dvadtsatiletie zhurnala ‘Trudy Kievskoi dukhovnoi Akademii’ (186o-1879) [The Twentieth Anniversary of the 'Works of the Kyiv Theological Academy' Journal (186o-1879)]," TKDA 7 (1881): 336-38; Mikhail (Luzin), Ep., Bibleiskaia nauka. Kniga pervaia: Ocherk istorii tolkovaniia 
So, Orthodox Biblical scholars were forced to seek methodological and ideological allies and supporters in the West - among Protestant and Catholic conservative theologians, who rejected so-called "modernism," whose core was rationalistic biblical criticism. Therefore, it would be very interesting and heuristically fruitful to explore the historical foundations that facilitated the emergence of a specifically Orthodox Christian tradition of rational (and therefore critical) academic biblical research - along with the traditional exegesis and apologetics. Let us examine this further.

\section{When and Why Ukrainian Orthodox Christian Biblical Studies Emerged: Objective Requirements, Needs, and Challenges}

First, let us say a few words about a key point of how Christian biblical studies emerged and self-identified. This area of research became a logical and historical synthesis of traditional religious knowledge grounded on the Revelation and academic knowledge obtained through certain rationalized procedures. Theology sought to engage science to test its own judgments and development, and to logically deduce and justify a system of its tenets. So, what is the specific need of Christian tradition regarding the study of the Bible?

It is the need for a rational and critical authentication of its own textus receptus, the biblical text adopted by a certain Church for its worship and preaching. On the one hand, the God-inspired nature of the content and meaning of Scripture and the Word of God as well as its structure determined by the ecclesiastic experience (canons) will always be dogmatized invariants immune to rational criticism. However, critical validation may quite apply to specific historical, linguistic, and cultural parameters of the adopted version (revisions) of the text.

Historically, it generated the oldest biblical study disciplines, such as biblical textual criticism, canonical history, the history of text application, and the history of its translations. These disciplines have synthesized faith in the Bible as the God-inspired Scripture and faith in the sanctity of the canon accepted by the Church on the one hand, and the academic validation of its specific versions on the other hand. The early patristic examples of such a synthesis include the Eastern Christian reconstructions of the Greek Septuagint (Hexapla and Octapla by Origen) and the Western Christian translation and revision of the Latin Bible (Vulgate by Jerome of Stridonium and Abbot Alcuin).

It is important to underscore that the local denominational subcultures (Slavic Orthodox being one of the oldest) acquired their own basic versions of the sacred text by means that were no longer based on mystical revelation, but rather cultural means, through translations. This fact increased the sense that some kind of rational verification was needed.

Biblii [Biblical Studies. Book One: Review of the History of Biblical Interpretation], ed. N. I. Troitsky (Tula, 1898), 124-25, 134-35; S. M. Solskii, "Obozrenie trudov po izucheniiu Biblii v Rossii s XV veka do nastoiaschego vremeni [Review of Research Works on the Bible in Russia from the 15th Century to the Present]," Pravoslavnoe obozrenie 1.6 (1869): 817; G. V. Florovskii, Prot., Puti russkogo bogosloviia [The Directions of Russian Theology] (Moscow: Institut russkoi tsivilizatsii, 2009), 257-59, 448-50, 46o-62. 
Accordingly, Ukrainian Orthodox biblical studies were first able to reveal their identity and distinction from a simple compilation of "alien" theories and research practices at the time when they rendered academic and critical (primarily textual and linguistic) validation of the Church Slavonic Bible as the primary text of faith doctrine and the liturgical tradition. No wonder that this validation was declared a "special objective" of Orthodox Christian biblical studies. ${ }^{12}$ The most important stages in the history of Slavic Bible studies included the following: 1) reconstructions of the so-called Cyril and Methodius biblical liturgical tradition along with the creation of the first complete Church Slavonic manuscript of the Bible (Gennadiivskyi manuscript, 1499), 2) the textual exegetic work of Maximus the Greek and the work of scribes of the Ostroh Circle, ultimately incorporated in the full Church Slavonic incunabula (Ostroh Bible, 1581), 3) later revisions, especially the Moscow Early Printed Bible, 1663, and 4) the so-called Petrovsko-Elizavetynska Bible from the mid-18th century.

These efforts have become the core of Orthodox biblical studies. So, it was not a coincidence that the Slavic Bible studies were considered a priority area which gave birth to "probably the only own and original academic school." 13

While the Bible was further explored as the Holy Scripture, a historical evolution took place in Ukraine. For centuries, compilations of biblical texts were disseminated primarily for liturgical purposes: The Liturgical Gospels, The Books of Apostles, The Book of Psalms, and The Book of Paroemias. Some books were also intended for private readings. The so-called Explanatory Psalter and The Prophets, Interpretative Gospels and Teaching Gospels, The Conversations, The Homilies, and individual biblical books were compiled. They contained Slavic translations of patristic biblical commentaries: Athanasius the Great, Basil the Great, John Chrysostom, Gregory of Nyssa, Gregory the Great, Cyril of Alexandria, Jerome of Stridonium, Hesychius of Jerusalem, Hippolytus of Rome, Ephraim the Syrian, Theodoret of Cyrus, and Theophylact of Bulgaria. ${ }^{14}$

A specific thing about the Orthodox Christian liturgical use of the Bible was that, by the end of the 15th century, only fragments and certain collections of the Holy Scripture were available in the Church Slavonic language. The first complete manuscript of the Bible in Church

12 N. N. Glubokovskii, Russkaia bogoslovskaia nauka vyeie istoricheskom razvitii i noveishem sostoianii [The Historical Development and Modern Status of Russian Theological Studies] (Warsaw, 1928; Moscow, 2002), 43.

13 Yannuarii (Ivliev), Archim., "Bibleistika v Russkoi Pravoslavnoi Tserkvi v XIX v. [Bible Studies in the Russian Orthodox Church in the 19th Century]," Pravoslavnoe bogoslovie na poroge tretiego tysiacheletiia: Bogoslovskaia konferentsiia RPTS (Moskva, 7-9 fevralia 2000 g.) (Moscow, 2000), 33; B. A. Tikhomirov and A. A. Alekseev, "Bibleistika v Rossii (Obzor problematiki) [Biblical Studies in Russia: An Overview]," in Pravoslavnaia Entsiklopediia, vol. 5 (Moscow: Tserkovno nauchnyi tsentr "Pravoslavnaia Entsiklopediia," 2002), 45.

14 A. A. Alekseev and A. P. Likhachev, Bibliia. Slovar knizhnikov i knizhnosti Drevnei Rusi. Vypusk 1 (XI - pervaia polovina XIVv.) [The Bible: A Dictionary of Scribes and Book Learning in Ancient Rus. Vol. 1 (From the nth - to the First Half of the 14th Centuries)], ed. D. S. Likhachev (Leningrad: Nauka, 1987), 74-77; V. I. Ulianovskyi, Istoriia tserkvy ta relihiinoi dumkyv Ukraini [The History of the Church and of Religious Thought in Ukraine], book 2: Seredyna XV — kinets XVI st. (Kyiv: Lybid, 1994), 14. 
Slavonic, the so-called Gennadiivskyi manuscript, was made in 1499 in Novgorod the Great. It became the basis for the famous Ostroh Bible that was made on this terrain. This event raised the prestige of Slavic Christian culture and strengthened the foundation for biblical exegesis and theological works in the Orthodox Christian environment. ${ }^{15}$

Regular penetration of the national language into religious life was another important and powerful factor. Church Slavonic liturgical and biblical texts were often copied and revised, given local language specificity. The European Reformation, with its desire to make the Scripture understandable to everyone, strongly induced the emergence of translations in the national languages in these lands. Religious and national self-determination motives, in a larger European context, inspired the need for such translations. The Peresopnytsia Gospel manuscript has become the most famous translation of the Bible into Old Ukrainian. ${ }^{16}$

Already in the second half of the 16th and 17th centuries, Bible reading shaped the religious beliefs of broad groups of Orthodox Christians. From time to time ideas of different faiths were borrowed and adapted. This indicated the response of Orthodox Christians to Protestant and Catholic propaganda, and reflected the shift in perceptions and traditional religiosity brought about by the Reformation and Counter-Reformation. ${ }^{17}$

However, by the end of the 17 th century, the Bible was mostly studied as part of liturgical use, church service, or didactic private readings based on original samples of patristic exegesis or those revised by local commentators. This is well illustrated in the works of Herasym Smotrytskyi, Tarasii Zemka, Kyrylo Trankvilion-Stavrovetskyi, Zakharii Kopystenskyi, Yoanykii Haliatovskyi, and Petro Mohyla.

New developments take place already at the beginning and middle of the 18th century (the period of the so-called "synodical" reforms promoted by bishops Theophan Prokopovych, Dymytrii Tuptalo, and metropolitan Stefan Yavorskyi). First, the text of the Slavic Bible was continually acquired, though with a broader range of tools. Secondly, the trend was toward reception of Western biblical criticism, including linguistic, literary, and historical. At the Kyiv Collegium (Academy), this evolution became particularly apparent starting from the 1730s when Prokopovych's protégé, Symon Todorskyi, trained at a pietistic university in Germany, implemented a fundamentally new tradition of learning other languages, including reading and studying the Bible. He initiated Hebrew studies and linguistic studies of the Bible at the Kyiv Academy. His innovation was to study the Hebrew language as a biblical one. This approach may have been borrowed from the Protestants, but it was a kind of "cultural revolution" for Orthodox biblical studies. The revolution consisted in the fact that the Masoretic Bible text was taken as one of the fully legitimate sources for the development of Todorskyi's own tradition.

15 See S. M. Solskii “Ostrozhskaia Bibliia v sviazi s tseliami i vidami yeia izdatelia [The Ostroh Bible in Connection with the Intentions and Views of Its Publisher]," TKDA 7 (1884): 293-320.

16 I. I. Ohienko, Peresopnytska Yevanheliia 1556-1561 rr. [The 1556-1561 Peresopnytsia Gospel] (Warsaw: Synodal Printing House, 1930), reprinted from the Put Pravdy Journal 1 (1930).

17 M. V. Dmitriev, Pravoslavie i Reformatsiia. Reformatsionnye dvizheniia v vostochnoslavianskikh zemliakh Rechi Pospolitoi vo vtoroi polovine XVIv. [Orthodoxy and the Reformation. Reformation Movements in Eastern Slavic Lands of the Polish-Lithuanian Commonwealth in the Second Half of the 16th Century] (Moscow: Izdatelstvo MGU, 1990); Ulianovskyi, Istoriia tserkvy, 7-8, 52-53. 
Importantly, this revolution also included the use of methods of linguistic, literary, and historical criticism of the Bible, which had already been developed by European biblical studies in the 18th century. Therefore, comparison of the Slavic biblical text with not just the Greek LXX but also with the Jewish Masoretic text resulted in the need to raise and address not only textual issues but also those of a linguistic, literary, historical and cultural nature. This happened due to differences of the LXX and Masoretic texts, both of which became dogmatically relevant to the Orthodox Christian tradition from the second half of the 18th century. This is how the new critical trend, and at the same time original Orthodox Christian biblical studies, in contrast to the borrowed "high criticism" of the Bible, started to evolve in the Orthodox Christian biblical culture. The monopoly of exegesis as a dogmatised interpretation started to gradually disappear. Exegesis did not disappear, but somewhat gave in to the biblical criticism that was expanding its boundaries. Biblical studies per se started to evolve and became a new, critical element of biblical research.

This "cultural revolution," with its focus on linguistic and literary criticism and comparative textual studies of LXX and Masoretic texts improved the Orthodox Slavic textus receptus. Kyivan researchers, followers of Simon Todorskyi's school, played a decisive role in producing the Moscow early printed Bible (Epyphanii Slavynetskyi) and the Peter and Elizabeth Bible (Theophylact Lopatynskyi, Symon Todorskyi, Yakiv Blonnytskyi, Varlaam Liashchevskyi, Gedeon Slomynskyi). ${ }^{18}$

The "cultural revolution" re-emerged from a new angle in the nineteenth century in connection with attempts to produce one more Orthodox Christian textus receptus - the Russian Bible. The experience of the Russian Bible Society and the development of the so-called Synodical translation were based on, among other things, the comparison of the LXX text with the Masoretic one as well as textual, linguistic, literary, and historical criticism to preserve the authenticity of the text and meaning of Scripture during translation. This prompted recourse to European biblical criticism experience and efforts to achieve better reception. ${ }^{19}$

The experience of the Kyiv Theological Academy of the 19th and early 2oth centuries, embodied in the personal research practices of eminent professors, enables us to point out a few more aspects characteristic of the Ukrainian tradition of Biblical studies.

\section{Orthodox Christian Biblical Studies at the Kyiv Theological Academy of the 19th and Early 2oth Centuries: In Pursuit of Identity}

The stories of the personal life and research of the professors that belonged to this institution provide interesting evidence of how Ukrainian Orthodox biblical studies shaped their own identity as they interacted with the European experience.

18 Mikhail (Luzin), Ep. Bibleiskaia nauka, 117; S. M. Solskii “Obozrenie trudov po izucheniiu Biblii v Rossii," Pravoslavnoe obozrenie 1.4 (1869): 554-57, 562-63, 577; 1.6 (1869): 803.

19 See S. I. Golovashchenko, “Pro rol 'Mohylianskoii doby’ v stanovlenni i rozvytku kyivskoho dukhovnoakademichnoho bibliieznavstva [The Role of the 'Mohyla Era' in the Evolution and Development of Kyiv Theological-Academic Biblical Studies]," Trudy Kyivskoi Dukhovnoi Akademii 19 (2013): 100-07. 
A very remarkable story started to unfold from the first third of the nineteenth century. It was associated with the transformation of one of the traditional foundations of Orthodox biblical exegesis, namely its intimate connection with liturgical practice and the pastoral activities of priests. This focus of Orthodox biblical studies was bequeathed by the Apostolic Fathers of the Church. As noted above, the patristic biblical homiletic heritage served as the basis of church practices for centuries. So, what do we observe in the nineteenth century?

Several prominent KTA professors, who were clergymen, well demonstrated their affiliation with the academic dimension of a rational theological school, thus significantly expanding the traditional area of a priest or monk (liturgy, preaching or moral instruction). Academic biblical education was proclaimed to be the foundation for the work of a theologian or a church apologist. ${ }^{20}$ A cleric (priest, bishop) who instructed biblical knowledge now took an active part in academic discourse and utilized the whole available range of academic knowledge and didactic techniques. In a unique way, educated representatives of the Orthodox Christian clergy became organically integrated into academic culture. And it was not a "scholarism" for show, but a truly critical intellectual position integrated into the European cultural context.

As for instance, the Archimandrite, later Bishop Inokentii (Borysov) and KTA Rector in 1830-1839, made significant efforts to promote the historical method of Bible study and the role of biblical history. ${ }^{21}$ This was intended to compensate for an excessive allegoric approach to biblical interpretations and theological speculations. ${ }^{22}$

Bishop Filaret (Filaretov), KTA Professor and Rector in the 186os, exemplified an Orthodox theologian scholar versed in European biblical research. Filaret was famous for his thorough and well-structured lectures on the Bible, and encouraged student research. His library, a model one at the time, was replenished regularly by books brought from abroad. It was used not only by the professor but by his students too. Filaret was a promoter of systemic biblical education at the KTA. His proposals incorporated in the 1869 Academic Statute in fact marked the introduction of the European model of a research university. ${ }^{23}$

Finally, Bishop Irenei (Orda), who was profoundly familiar with international theological and academic achievements, ${ }^{24}$ translated the academic traditions of Bible studies into church education of the middle level — as the rector of the Kyiv Theological Seminary and the author of the first exemplary textbooks and manuals for the study of individual sections of the Bible. ${ }^{25}$

20 F. G. Yeleonskii, “Otechestvennye trudy po izucheniiu Biblii v XIX veke [Local Works on Bible Studies in the 19th Century]," Khristianskoe chtenie 1 (1901): 637; M. V. Nikolskii, "Nasha bibleiskaia nauka [Our Biblical Studies]," Pravoslavnoe obozrenie 2 (1875): 186.

21 Titov, Imperatorskaia Kievskaia Dukhovnaia Akademiia, 359-64.

22 Florovskii, Puti russkogo bogosloviia, 461.

23 See Korolkov, "Preosviaschennyi Filaret," 11, 20-21, 40-42.

24 See Kh. M. Orda, “Apologeticheskaia i polemicheskaia literatura na Zapade protiv sochineniia Ernesta Renana 'Vie de Jesus' [Apologetic and Polemic Literature in the West against Ernest Renan's Vie de Jesus]," TKDA 9 (1864): 71-16o; Kh. M. Orda, "Obozrenie inostrannoi dukhovnoi literatury [Review of Foreign Spiritual Literature]," TKDA 10 (1864): 237-6o.

25 Kh. M. Orda, Rukovodstvo k posledovatelnomu chteniiu prorocheskikh knig Vetkhogo Zaveta [A Guide to the Consistent Reading of Prophetic Books of the Old Testament] (Kyiv, 1871); Kh. M. Orda, 
These clergymen academics furthered the evolvement of the original Orthodox biblical studies that integrated the European experience. Each of them overcame the traditional image of an Orthodox monk or bishop as a "pious ignorant" who eschews reason for piety and avoids academic research for loyalty to patristic thoughts. Combining fidelity to the dogmatic tradition with a modern academic critical approach became an important systemic theme for Orthodox biblical studies.

Several more KTA representatives, through their personal life and professional stories, also illustrated a quest for unique identity undertaken by Orthodox biblical studies. For instance, Stepan Solskyi paid major attention to studying the Bible as the dominant of the national spiritual culture. ${ }^{26}$ At the same time, he was also known for his relevant re-thinking of Western biblical knowledge in the Orthodox way. He developed a concept of the "Orthodox Christian isagogic introduction." ${ }^{27}$ Yakym Olesnytskyi demonstrated a profound conversance - exemplary for Orthodox Christians - with biblical archaeology and culture, biblical languages, and textual, historical, cultural, literary and linguistic criticism of the Bible. In his writings he demonstrated the prospects of the heuristic potential of history, art, and linguistic and literature studies. ${ }^{28}$

Dymytrii Bogdashevskyi (later Bishop Vasylii) was an apologist of historical biblical narrative ${ }^{29}$ and literal interpretation of the supernatural and miraculous element revealed in

Rukovodstvennoe posobie k ponimaniiu Psaltyri: Sost. prepodavatel Kievskoi Dukhovnoi seminarii sviasch. Kh. Orda [A Guide to Understanding the Book of Psalms, Compiled by a Kyiv Theological Seminary Lecturer and Priest] (Kyiv, 1882).

26 S. M. Solskii, "Upotrebleniie i izuchenie Biblii v Rossii," Pravoslavnoe obozrenie 27.10 (1868): 145-80; 27.11 (1868): 251-70; S. M. Solskii, “Obozrenie trudov po izucheniiu Biblii v Rossii," Pravoslavnoe obozrenie 1.2 (1869): 19o-221, 1.4 (1869): 538-77; 1.6 (1869): 797-822; S. M. Solskii “O bibleiskom mirosozertsanii v zhizni drevnerusskogo naroda (Rech, skazannaia v torzhestvennom sobranii Kievskoi dukhovnoi Akademii 28 sentiabria 1878 g.) [Biblical Worldview in the Life of the Old Rus People (Speech Delivered at the Solemn meeting of the Kyiv Theological Academy on 28 September 1878)]," TKDA 11 (1878): 201-37; Solskii, “Ostrozhskaia Bibliia [Ostroh Bibile]," TKDA 7 (1884): 293-320.

27 S. M. Solskii, "Kakov mozhet byt sostav nauchnykh vvedenii v knigi Sviaschennogo Pisaniia v nastoiaschee vremia [What Can the Composition of the Academic Introduction to the Holy Scriptures in Our Time Be]," TKDA 3 (1887): 358-76.

28 A. A. Olesnitskii, "Drevnerusskaia muzyka i penie [Old Rusian Music and Singing]," TKDA 11 (1871): 107-61; 12 (1871): 368-417; A. A. Olesnitskii, "Ritm i metr vetkhozavetnoi poezii [Rhythm and Cadence of Old Testament Poetry]," TKDA 10 (1872): 242-94; 11 (1872): 403-72; 12 (1872): 501-92; A. A. Olesnitskii, "Tendentsioznye korrektury iudeiskikh knizhnikov (soferimov) v chtenii Vetkhogo Zaveta [Tendentious Proofreads of Jewish Scribes (Sopherims) in the Reading of the Old Testament]," TKDA 5 (1879): 3-54.

29 D. I. Bogdashevskii, "O Evangeliiakh i evangelskoi istorii (protiv sovremennogo ratsionalizma). Publichnoe chtenie [Gospels and Evangelical Stories (Against Modern Rationalism). Public Readings]," TKDA 2 (1902): 269-302; D. I. Bogdashevskii, "Istoricheskii kharakter knigi Deianii Apostolskikh [The Historical Character of the Books of the Apostles]," TKDA 11 (1909): 381-425. 
that narrative. ${ }^{30}$ In his deliberations, however, he came close to the problem of a comparison of scientific and non-scientific knowledge, and rational and non-rational elements of cognition. Archpriest Olexandr Glagolev emphasized the universal value of the Bible in the unity of the Old and New Testaments. ${ }^{31}$ On this basis, he overcame the confessional limitations and xenophobia not only in public and church life but also in biblical studies. His idea of the "ideological emancipation" of the Orthodox Christian perception of the Old Testament and the image of Jews $^{32}$ organically complemented his life experience. While being an Orthodox Christian cleric, Glagolev rejected Orthodox Christian anti-Semitism; he acted as an expert in the Beilis case and personally stopped those who engaged in pogroms. ${ }^{33}$

Glagolev's position on the importance of the Bible in spiritual and social life as well as presentations by Volodymyr Rybinskyi on biblical education and promotion of the Bible have become very important for the Orthodox Christian understanding of the place of the Bible in culture, society, and spiritual life of each individual. ${ }^{34}$ These issues were actively deliberated and debated in the Western world, especially in the Catholic and Protestant communities. Comparing the Orthodox Christian experience to the foreign one was important for the identity of Orthodox Christian biblical studies. Finally, Rybinskyi's analysis of European rationalistic

30 D. I. Bogdashevskii, "O Evangelskikh chudesakh (Zametka protiv ratsionalistov i v chastnosti protiv grafa L. Tolstogo) [Evangelical Wonders: An Article Against the Rationalists and Particularly Against Count L. Tolstoy]," TKDA 8 (1900): 473-93; D. I. Bogdashevskii, "Deistvitelnost voskreseniia mertvykh, po ucheniiu sv. ap. Pavla [The Reality of the Resurrection of the Deceased According to the Teaching of Saint Paul, the Apostle]," TKDA 1 (1902): 61-98; D. I. Bogdashevskii, "Khristos Spasitel kak chudotvorets [Christ the Savior as Wonderworker]," TKDA 10 (1911): 243-74; 11 (1911): 377-404.

31 A. A. Glagolev, Priest, "Neprekhodiaschee znachenie Vetkhogo Zaveta. Bibliologicheskaia zametka na: Die bleibende Bedeutung des Alten Testaments, von Emil Kautzsch, Tübingen und Leipzig [The Lasting Importance of the Old Testament. Bibliological Article on: Die bleibende Bedeutung des Alten Testaments, von Emil Kautzsch, Tübingen und Leipzig]," TKDA 11 (1902): 491-504; A. A. Glagolev, Priest, "Vetkhii Zavet i yego neprekhodiaschee znachenie v khristianskoi Tserkvi [The Old Testament and Its Lasting Importance for the Christian Church]," TKDA 11 (19o9): 353-80; 12 (1909): 517-50.

A. A. Glagolev, Priest, "Sionistskoe dvizhenie v sovremennom yevreistve i otnoshenie etogo dvizheniia k vsemirno-istoricheskoi zadache bibleiskogo Izrailia [The Zionist Movement in Modern Judaism and the Relation of this Movement to the Global Historical Objective of Biblical Israel]," TKDA 4 (1905): 513-65; A. A. Glagolev, Priest, "Mnimoe prorochestvo Vetkhogo Zaveta o Rossiiskoi Gosudarstvennoi Dume [The Imaginary Prophecy of the Old Testament about the Russian State Duma]," TKDA 12 (1905): 66o-63; A. A. Glagolev, Priest, "Sedmoi vsemirnyi sionistskii kongress v yevreistve [The Seventh World Zionist Congress in Jewry]," TKDA 2 (1906): 328-41.

M. L. Tkachuk and S. I. Golovashchenko, "Glagolev Oleksandr Oleksandrovych [Glagolev Oleksandr Oleksandrovych]," in Kyivska dukhovna akademiia v imenakh, vol. 1, ed. M. Tkachuk (Kyiv: Vydavnychyi dim “Kyievo-Mohyliansla akademiia," 2015), 373-74. V. P. Rybinskii, "Bibliia dlia detei [The Bible for Children]," TKDA 1 (1897): 3-34; V. P. Rybinskii, "O Biblii (Publichnoe chtenie) [On the Bible: Public Readings]," TKDA 3 (1902): 359-82. 
biblical criticism and the exploration of the limits for the application of academic methods in studying the Bible from the Orthodox Christian perspective were very valuable in this respect. ${ }^{35}$

Here, we would like to underscore another important point directly related to the identity of the Ukrainian tradition in biblical studies. The fact that the Kyiv Theological Academy of the 19th and early 20 th centuries was the leading Orthodox Christian theological school was crucial to the ways in which the foreign experience of biblical studies was utilized, and what kind of criticism was addressed towards it. We are talking about another systemic feature of Kyiv Orthodox Christian biblical studies. It is a personal and professional life drama that unfolded when theological and academic discourses came together (or even collided, if you wish). Loyalty to the Orthodox dogmatic tradition came across and interplayed in a controversial manner with the personal experiences of professionals who were educated in a European way and familiar with significant achievements of various academic disciplines of the time.

\section{Conclusions}

It has proven to be extremely interesting and heuristically fruitful to explore some historical grounds that facilitated the emergence of a specifically Orthodox Christian tradition of academically rational (and therefore critical) Bible studies along with traditional exegesis and apologetics.

The Ukrainian Orthodox tradition of biblical studies revealed its identity and distinguished itself from a simple compilation of "alien" theories and research practices specifically when it undertook an academically critical (primarily textual and linguistic) approach to the study of the Church Slavonic Bible as a "prototext" of its own religious and liturgical tradition.

As the Bible was explored in this part of the world as the Holy Scripture, the medieval liturgical use and homiletic exegesis based on patristic examples underwent a historical evolution to a modern (17-18 centuries) orientation towards linguistic and literary criticism and comparative textology.

Giving a new hermeneutic status to the Hebrew language as a biblical language was another important indicator of the modern identity of Orthodox Christian biblical studies.

Personal research practices of Kyiv Theological Academy professors of the 19th and early 2oth centuries also revealed new identity aspects of the Orthodox Christian tradition of biblical studies. They demonstrated that the Orthodox academic clergy had integrated into the academic dimension of a rationally organized theological school, and the European cultural context. They explored Western biblical studies from an Orthodox Christian perspective. They opened prospects for the use of the heuristic potential of various academic disciplines and rationalistic

V. P. Rybinskii, "Vavilon i Bibliia (po povodu rechi Delicha 'Babel und Bibel') [Babylon and the Bible: On the Occasion of Delitzsch's Speech 'Babel und Bibel']," TKDA 5 (1903): 113-44; V. P. Rybinskii, "K voprosu ob otnoshenii Biblii k Vavilonu [rets. na:] H. V. Hiprecht, 'Die Ausgrabungen im BelTempel zu Nippur,' Leipzig, 1903 [On How the Bible Relates to Babylon [Review of] H. V. Hiprecht, Die Ausgrabungen im Bel-Tempel zu Nippur, Leipzig, 1903]," TKDA 1 (1904): 46-58; V. P. Rybinskii, "Bibleiskaia vetkhozavetnaia kritika [Biblical Criticism on the Old Testament]," TKDA 12 (19o8): $575^{-613}$ 
criticism in the Orthodox Christian exploration of the Bible. The comparison with foreign experience shaped the Orthodox Christian view on the place of the Bible in culture, society, and spiritual life of an individual.

Combining loyalty to the dogmatic tradition with critical academic research and the personal experience of Kyivan Bible researchers as academics educated in a European manner was a significant systemic theme for Orthodox Christian biblical studies. The recognition and awareness of specific features of the Orthodox Christian exploration of the Bible in the Ukrainian religious, cultural and educational context remain important to the present day.

\section{Bibliography}

Alekseev, A.A., and A. P. Likhachev. Bibliia. Slovar knizhnikov i knizhnosti Drevnei Rusi. Vypusk 1 (XI-pervaia polovina XIVv.) [The Bible:A Dictionary of Scribes and BookLearning in Ancient Rus. Vol. 1 (From the 11th - to the First Half of the 14th Centuries)]. Edited by D. S. Likhachev. Leningrad: Nauka, 1987.

Bogdashevskii, D.I. "Deistvitelnost voskreseniia mertvykh, po ucheniiu sv. ap. Pavla [The Reality of the Resurrection of the Deceased According to the Teaching of Saint Paul, the Apostle]." TKDA 1 (1902): 61-98.

Bogdashevskii, D.I. "Istoricheskii kharakter knigi Deianii Apostolskikh [The Historical Character of the Books of the Apostles]." TKDA 11 (1909): 381-425.

Bogdashevskii, D.I. "Khristos Spasitel kak chudotvorets [Christ the Savior as Wonderworker]." TKDA 10 (1911): 243-74; 11 (1911): 377-404.

Bogdashevskii, D.I. "O Evangelskikh chudesakh (Zametka protiv ratsionalistov i v chastnosti protiv grafa L. Tolstogo) [Evangelical Wonders: An Article Against the Rationalists and Particularly Against Count L. Tolstoy]." TKDA 8 (1900): 473-93.

Dmitriev, M. V. Pravoslavie i Reformatsiia. Reformatsionnye dvizheniia v vostochnoslavianskikh zemliakh Rechi Pospolitoi vo vtoroi polovine XVI v. [Orthodoxy and the Reformation. Reformation Movements in Eastern Slavic Lands of the Polish-Lithuanian Commonwealth in the Second Half of the 16th Century]. Moscow: Izdatelstvo MGU, 199o.

Florovskii, G.V., Prot. Puti russkogo bogosloviia [The Directions of Russian Theology]. Moscow: Institut russkoi tsivilizatsii, 2009 .

Glagolev, A.A., Priest. "Mnimoe prorochestvo Vetkhogo Zaveta o Rossiiskoi Gosudarstvennoi Dume [The Imaginary Prophecy of the Old Testament about the Russian State Duma]." TKDA 12 (1905): 66o-63.

Glagolev, A.A., Priest. "Neprekhodiaschee znachenie Vetkhogo Zaveta. Bibliologicheskaia zametka na: Die bleibende Bedeutung des Alten Testaments, von Emil Kautzsch, Tübingen und Leipzig [The Lasting Importance of the Old Testament. Bibliological Article on: Die bleibende Bedeutung des Alten Testaments, von Emil Kautzsch, Tübingen und Leipzig]." TKDA 11 (1902): 491-504.

Glagolev, A.A., Priest. "Sedmoi vsemirnyi sionistskii kongress v yevreistve [The Seventh World Zionist Congress in Jewry]." TKDA 2 (1906): 328-41.

Glagolev, A.A., Priest. "Sionistskoe dvizhenie v sovremennom yevreistve i otnoshenie etogo dvizheniia k vsemirno-istoricheskoi zadache bibleiskogo Izrailia [The Zionist Movement 
in Modern Judaism and the Relation of this Movement to the Global Historical Objective of Biblical Israel]." TKDA 4 (1905): 513-65.

Glagolev, A.A., Priest. "Vetkhii Zavet i yego neprekhodiaschee znachenie v khristianskoi Tserkvi [The Old Testament and Its Lasting Importance for the Christian Church]." TKDA 11 (1909): 353-80; 12 (1909): 517-50.

Glubokovskii, N. N. Russkaia bogoslovskaia nauka v yeie istoricheskom razvitii i noveishem sostoianii [The Historical Development and Modern Status of Russian Theological Studies]. Warsaw, 1928; Moscow, 2002.

Golovashchenko, S.I. "Bibliieznavstvo v Kyivskii dukhovnii akademii (XIX - poch. XX st.): deiaki poniatiino-terminolohichni pytannia doslidzhennia [Biblical Studies at the Kyiv Theological Academy (the 19th and Early 2oth Centuries): Some Conceptual and Terminological Issues of Research]." Naukovi zapysky NaUKMA 154 (2014): 84-88.

Golovashchenko, S.I. "Pro rol 'Mohylianskoii doby' v stanovlenni i rozvytku kyivskoho dukhovnoakademichnoho bibliieznavstva [The Role of the 'Mohyla Era' in the Evolution and Development of Kyiv Theological-Academic Biblical Studies]." Trudy Kyivskoi Dukhovnoi Akademii 19 (2013): 100-07.

Golovashchenko, S.I. "Bibliieznavstvo v Kyivskii dukhovnii akademii (XIX - poch. XX st.): stanovlennia i rozvytok [Biblical Studies at the Kyiv Theological Academy (the 19th and Early 2oth Centuries): Evolvement and Development]." Manuscript. Thesis for Doctor of Philosophy Degree in Specialization o9.0o.11 — Religious Studies, Drahomanov National Pedagogical University, Kyiv, 2015.

Golovashchenko, S. I. Doslidzhennia ta vykladannia Biblii v Kyivskii dukhovnii akademii XIXpochatku XX st. [Research and Instruction of the Bible at the Kyiv Theological Academy in the 19th and Early 2oth Centuries]. Kyiv: Vydavnychyi viddil Ukrainskoi Pravoslavnoi Tserkvy, 2012.

Kolodnyi, A., and A. Lobovyk, eds. Relihiieznavstvo: predmet, struktura, metodolohiia [Religious Studies: Subject Matter, Structure, Methodology]. Kyiv: Viddil relihiieznavstva Instytutu filosofii NAN Ukrainy, 1996.

Korolkov, I.N. "Dvadtsatiletie zhurnala 'Trudy Kievskoi dukhovnoi Akademii' (186o-1879) [The Twentieth Anniversary of the 'Works of the Kyiv Theological Academy' Journal (186o1879)]." TKD1 (1881): 111-23; 3 (1881): 357-66; 7 (1881): 324-6o; 8 (1881): 417-50; 9 (1881): 5398; 10 (1881): 217-32; 12 (1881): 488-509; 5 (1882): 74-100; 8 (1882): 427-64; 9 (1882): 73-121; 12 (1882): 449-64.

Korolkov, I.N. "Preosviaschennyi Filaret, Ep. Rizhskii, kak rektor KDA [His Grace Filaret, Bishop of Riga as the Rector of the KTA]." TKDA 12 (1882): 1-96.

Malyshevskii, I.I. "Istoricheskaia zapiska o sostoianii akademii v minuvshee piatidesiatiletie [Historical Review of the Status of the Academy in the Past Half-Century]." TKDA 11 (1869): 64-138.

Men, A., Prot. "K istorii russkoi pravoslavnoi bibleistiki [On the History of Russian Orthodox Biblical Studies]." Bogoslovskie trudy 28 (1987): 272-90.

Men, Alexandr, Prot. Bibliologicheskii slovar [Bibliological Dictionary]. In 3 vols. Moscow: Fond Aleksandra Menia, 2002. 
Mikhail (Luzin), Ep. Bibleiskaia nauka. Kniga pervaia: Ocherk istorii tolkovaniia Biblii [Biblical Studies. Book One: Review of the History of Biblical Interpretation]. Edited by N. I. Troitsky. Tula, 1898.

Nikolskii, M.V. "Nasha bibleiskaia nauka [Our Biblical Studies]." Pravoslavnoe obozrenie 2 (1875): 184-96.

Ohienko, I. I. Peresopnytska Yevanheliia 1556-1561 rr. [The 1556-1561 Peresopnytsia Gospel]. Warsaw: Synodal Printing House, 1930. (Reprinted from the Put Pravdy Journal 1, 1930.)

Olesnitskii, A.A. "Drevnerusskaia muzyka i penie [Old Rusian Music and Singing]." TKDA 11 (1871): 107-61; 12 (1871): 368-417.

Olesnitskii, A.A. "Ritm i metr vetkhozavetnoi poezii [Rhythm and Cadence of Old Testament Poetry]." TKDA 10 (1872): 242-94; 11 (1872): 403-72; 12 (1872): 501-92.

Olesnitskii, A.A. "Tendentsioznye korrektury iudeiskikh knizhnikov (soferimov) v chtenii Vetkhogo Zaveta [Tendentious Proofreads of Jewish Scribes (Sopherims) in the Reading of the Old Testament]." TKDA 5 (1879): 3-54.

Orda, Kh.M. "Apologeticheskaia i polemicheskaia literatura na Zapade protiv sochineniia Ernesta Renana 'Vie de Jesus' [Apologetic and Polemic Literature in the West against Ernest Renan's Vie de Jesus].” TKDA 9 (1864): 71-16o.

Orda, Kh.M. "Obozrenie inostrannoi dukhovnoi literatury [Review of Foreign Spiritual Literature]." TKDA 10 (1864): 237-6o.

Orda, Kh. M. Rukovodstvennoe posobie k ponimaniiu Psaltyri: Sost. prepodavatel Kievskoi Dukhovnoi seminarii sviasch. Kh. Orda [A Guide to Understanding the Book of Psalms, Compiled by a Kyiv Theological Seminary Lecturer and Priest]. Kyiv, 1882.

Orda, Kh. M.Rukovodstvo k posledovatelnomu chteniiu prorocheskikh knig Vetkhogo Zaveta [A Guide to the Consistent Reading of Prophetic Books of the Old Testament]. Kyiv, 1871.

Rybinskii, V.P. "Bibleiskaia vetkhozavetnaia kritika [Biblical Criticism on the Old Testament]." TKDA 12 (1908): 575-613.

Rybinskii, V.P. "Bibliia dlia detei [The Bible for Children]." TKDA 1 (1897): 3-34.

Rybinskii, V.P. "K voprosu ob otnoshenii Biblii k Vavilonu [rets. na:] H.V. Hiprecht, 'Die Ausgrabungen im Bel-Tempel zu Nippur,' Leipzig, 1903 [On How the Bible Relates to Babylon [Review of] H. V. Hiprecht, Die Ausgrabungen im Bel-Tempel zu Nippur, Leipzig, 1903]." TKDA 1 (1904): 46-58.

Rybinskii, V.P. “O Biblii (Publichnoe chtenie) [On the Bible: Public Readings].” TKDA 3 (1902): $359-82$.

Rybinskii, V.P. "Vavilon i Bibliia (po povodu rechi Delicha 'Babel und Bibel') [Babylon and the Bible: On the Occasion of Delitzsch's Speech 'Babel und Bibel']." TKDA 5 (1903): 113-44.

Solskii, S.M. "Kakov mozhet byt sostav nauchnykh vvedenii v knigi Sviaschennogo Pisaniia v nastoiaschee vremia [What Can the Composition of the Academic Introduction to the Holy Scriptures in Our Time Be]." TKDA 3 (1887): 358-76.

Solskii, S.M. "Kratkii ocherk istorii Sviaschennoi bibliologii i ekzegetiki [Overview of the Story of Holy Bibliology and Exegetics]." TKDA 10 (1866): 157-90; 11 (1866): 305-42; 12 (1866): 466-5o6. 
Solskii, S. M. "Obozrenie trudov po izucheniiu Biblii v Rossii s XV veka do nastoiaschego vremeni [Review of Research Works on the Bible in Russia from the 15th Century to the Present]." Pravoslavnoe obozrenie 1.2 (1869): 19o-221; 1.4 (1869): 538-77; 1.6 (1869): 797-822.

Solskii, S.M. "Ostrozhskaia Bibliia v sviazi s tseliami i vidami yeia izdatelia [The Ostroh Bible in Connection with the Intentions and Views of Its Publisher]." TKDA 7 (1884): 293-320.

Solskii, S. M. "Upotreblenie i izuchenie Biblii v Rossii ot krescheniia Rusi i do XV v. [The Use and Study of the Bible in Russia from the Christianization of Rus Through the 15th Century]." Pravoslavnoe obozrenie 27.10 (1868): 145-80; 27.11 (1868): 251-70.

Tikhomirov, B.A., and A. A. Alekseev. "Bibleistika v Rossii (Obzor problematiki) [Biblical Studies in Russia: An Overview]." In Pravoslavnaia Entsiklopediia. Vol. 5: "Bessonov-Bonvech," 4548. Moscow: Tserkovno nauchnyi tsentr "Pravoslavnaia Entsiklopediia," 2002.

Titov, Fedor, Prof., Prot. Imperatorskaia Kievskaia Dukhovnaia Akademiia vyeie trekhvekovoizhizni i deiatelnosti (1615-1915 gg.): Istoricheskaia zapiska [The Imperial Kiev Theological Academy in Its Three Centuries of Life and Activity, 1615-1915: Historical Review]. Kyiv: Hopak, 2003.

Tkachuk, M.L., and S.I.Golovashchenko. "Glagolev Oleksandr Oleksandrovych [Glagolev Oleksandr Oleksandrovych]." In Kyivska dukhovna akademiia v imenakh, vol. 1, edited by M. Tkachuk, 373-74 (Kyiv: Vydavnychyi dim "Kyievo-Mohyliansla akademiia," 2015).

Ulianovskyi, V. I. Istoriia tserkvy ta relihiinoi dumky v Ukraini [The History of the Church and of Religious Thought in Ukraine]. In 3 books. Book 2: Seredyna XV-kinets XVI st. Kyiv: Lybid, 1994 .

Yannuarii (Ivliev), Archim. "Bibleistika v Russkoi Pravoslavnoi Tserkvi v XIX v. [Bible Studies in the Russian Orthodox Church in the 19th Century]." In Pravoslavnoe bogoslovie na poroge tretiego tysiacheletiia: Bogoslovskaia konferentsiia RPTS (Moskva, 7-9 fevralia 2000 g.), 3038. Moscow, 2000.

Yeleonskii, F.G. "Otechestvennye trudy po izucheniiu Biblii v XIX veke [Local Works on Bible Studies in the 19th Century]." Khristianskoe chtenie 1 (1901): 5-28, 633-60; 1 (1902): 39-64, 504-24; 2 (1902): 107-25.

Sergiy Golovashchenko is a philosopher and religious scholar. He lectures religious studies at the National University of Kyiv-Mohyla Academy. He is the author of Istoriia khrystyianstva (The History of Christianity, 1999), Bibliieznavstvo (Biblical Studies, 2001), Doslidzhennia ta vykladannia Bibliiv Kyivskii dukhovnii akademii XIX — pochatku XX st. (Research and Instruction of the Bible at the Kyiv Theological Academy in the 19th and Early 2oth Centuries, 2012). Most of his publications explore the history of biblical studies in Ukraine, particularly at the Kyiv Theological Academy. Sergiy Golovashchenko defended his Dr. Hab. Thesis in 2015. 